\title{
Procjena potreba učenika osnovne škole u svrhu planiranja socijalnopedagoških intervencija - standardizacija mjernog instrumenta
}

\author{
Dejana Bouillet \\ Sveučilište u Zagrebu, Učiteljski fakultet
}

Sažetak

U radu je prikazan proces razvoja mjernog instrumenta za pravovremenu identifikaciju problema u ponašanju učenika osnovnih škola, sa svrhom primjerenog poduzimanja potrebnih socijalnopedagoških intervencija1. Radi se o Upitniku za procjenu potreba učenika za socijalnopedagoškim intervencijama - verziji za učenike koji je kreiran i evaluiran u cilju standardizacije, planiranja i praćenja uspješnosti socijalnopedagoških intervencija u osnovnoj školi². Istraživanje je provedeno na uzorku 3301 učenika trećih, petih i sedmih razreda 43 osnovne škole iz 13 hrvatskih županija. Konačna verzija Upitnika sadrži 42 čestice koje mjere odnos učenika s vršnjacima, odnos prema obrazovanju, odnos prema obvezama, odnos s roditeljima, razinu roditeljske podrške, otvorenost u komunikaciji i interesima, odnos s razrednikom, zadovoljstvo sobom i permisivnost u odgoju. Pouzdanost, valjanost i objektivnost upitnika je zadovoljavajuća (Cronbach Alpha iznosi ,894).

Učenici su prema postignutim rezultatima na Upitniku grupirani u 3 skupine (učenike s poremećajima u ponašanju, učenike s teškoćama u ponašanju i učenike koji ne manifestiraju probleme u ponašanju). Utvrđeno je da prema tom kriteriju u hrvatskim osnovnim školama prosječno ima $12,88 \%$ učenika s problemima u ponašanju. U radu su ponuđene norme za grupiranje učenika u kategorije specifično vezano uz dob i spol učenika koje će se doraditi tijekom daljnje provedbe projekta.

Ključne riječi: učenici s problemima u ponašanju, pravovremena identifikacija, standardizacija mjernog instrumenta, socijalnopedagoške intervencije u osnovnoj školi

\section{Uvod}

Problemi u ponašanju učenika su među najzastupljenijim posebnim odgojno-obrazovnim potrebama koje imaju nepovoljan učinak na njihova obrazovna postignuća i socijalni razvoj. Radi se o učenicima čija ponašanja odstupaju od uobičajenih ponašanja primjerenih dobi, situaciji, kulturnim i društvenim normama u školi, obitelji i/ili širem okruženju, te imaju posljedice koje štetno djeluju na samog učenika i/ili okruženje i time otežavaju njihovu uspješnu socijalnu integraciju. $S$ takvim su ponašanjima povezane posljedice ponašanja i stanja koje treba usmjeravati, mijenjati i/ ili rješavati, a kojima se bave stručnjaci različitih struka i u različitim područjima. Skup problema u ponašanju, temeljem Standarda za terminologiju, definiciju, kriterije i način praćenja pojave poremećaja u ponašanju djece i mladih (Koller-Trbović, Žižak, Jeđud Borić, 2011), čine rizična ponašanja, teškoće u ponašanju i poremećaji u ponašanju. U probiru učenika mlađe školske dobi koji manifestiraju probleme u ponašanju, na uzorku 921 učenika iz 6 hrvatskih osnovnih škola, Pavin Ivanec

1 Mjerni instrument je razvijen u sklopu projekta „Razvoj modela socijalnopedagoških intervencija u osnovnoj školi“ koji se provodi uz potporu Agencije za odgoj i obrazovanje od 2015. godine.

2 Upitnik je tijekom istraživanja imenovan kao Upitnik za procjenu socijalnopedagoških potreba učenika, kako bi se izbjegla eventualna stigmatizacija sudionika istraživanja. 
(2015) je utvrdila da određene probleme u ponašanju (uključujući rizična ponašanja) manifestira $20 \%$ učenika u dobi od 7 do 10 godina. Pastor, Reuber i Duran (2012) su na reprezentativnom uzorku djece u dobi od 4 do 17 godina za SAD utvrdili da probleme u ponašanju prema Upitniku sposobnosti i teškoća učenika postiže 7\% djece. Abu-Rayya i Yang (2012) također zaključuju da je u Australiji u riziku razvoja ozbiljnih poremećaja u ponašanju 7,6\% djece mlađe od 15 godina. Ipak, podaci o prevalenciji problema u ponašanju djece osnovnoškolske dobi variraju od studije do studije i kreću se u rasponu od 3,5\% do 32,3\%, ovisno o kriterijima procjena (Conley, Marchant i Caldarella, 2014), pri čemu učitelji izvještavaju o prosječno tri učenika s problemima u ponašanju u svakom razredu (Conroy i Brown, 2004).

Istodobno, u literaturi se nailazi na opći konsensus o nepovoljnim posljedicama problema u ponašanju na proces i ishode učenja i socijalizacije (Gable, 2004; Boydell Brauner i Bowers Stephens, 2006; Barnett, 2011). Učenici koji u ranom razdoblju školovanja manifestiraju probleme u ponašanju su u povećanom riziku od akademskog neuspjeha, ranog napuštanja školovanja, odbacivanja od strane vršnjaka, ovisnosti o različitim psihoaktivnim sredstvima i upuštanja u maloljetničku delinkvenciju (Eklund i sur., 2009), a utvrđena je i značajna povezanost problema u ponašanju u ranom djetinjstvu s problemima u ponašanju tijekom adolescencije (Conroy i Brown, 2004). U literaturi je također dobro dokumentirano da su problemi u ponašanju djece i mladih izuzetno složena i promjenljiva pojava (Koller-Trbović i Žižak, 2012) koja iziskuje interdisciplinarne i složene odgovore društva i profesija.

Učenicima s problemima u ponašanju bave se različite profesije, a ovaj je rad usmjeren području djelovanja socijalnih pedagoga ${ }^{3}$, koje je shvaćeno kao vidljiva intervencija u živote djece i mladih, s ciljem poticanja njihovog razvoja, sudjelovanja u društvenom životu i učenja (Storø, 2013). Isti autor socijalnu pedagogiju razumije kao koncept rada s mladim osobama s različitim problemima u svakodnevnim životnim okolnostima, temeljem specifičnih praktičnih, teorijskih i znanstvenih koncepata. Kyricou i sur. (2009) socijalnu pedagogiju u praktičnom smislu definiraju kao akcije poduzete od strane odraslih osoba za promicanje osobnog razvoja, socijalnog obrazovanja i opće dobrobiti djeteta, u širokom rasponu obrazovnih i društvenih okruženja (predškolske i školske ustanove, obitelji, institucije za djecu i mlade, klubovi za mlade, državne ustanove i dr.), a Stevens (2010) kao društvene akcije sadržane u odgojno-obrazovnoj praksi usmjerenoj sprječavanju ili ublažavanju socijalnih problema djece i mladih, djelujući u smjeru poticanja pozitivnih promjena u ponašanju i uvjetima u kojima odrastaju i razvijaju se. Radi se o holističkom i osobnom pristupu djeci i mladima koji povezuje obrazovanje i društvenu skrb o djeci, a uključuje rad s pojedincem i socijalnim okruženjem (obitelj, školu, vršnjačke grupe, ali i širu zajednicu), s krajnjim ciljem afirmacije prava djece. U odgojno-obrazovnom kontekstu se socijalna pedagogija može opisati kao integralni pristup potrebama djece, s posebnim naglaskom na pet ključnih dimenzija: njegu i skrb, inkluziju, socijalizaciju, obrazovnu podršku i socijalno obrazovanje (Kyriacou, 2009). Prema tome, socijalna pedagogija u odgojno-obrazovnom okruženju nudi integralnu koncepcijsku osnovu za razvoj modela promocije socijalne dobrobiti učenika, koristeći socijalnopedagoške metode i strategije rada (Smith i Whyte, 2008) koje uključuju pedagoško, socijalno, korekcijsko i terapeutsko područje djelovanja (Žižak, 2010). Primjeri socijalnopedagoških intervencija u školskom okruženju su individualni savjetodavni rad s učenikom, osiguravanje vršnjačke i mentorske pomoći učeniku u

3 U radu se koristi pojam socijalni pedagog za osobe oba roda. 
učenju, sudjelovanje učenika u radionicama za razvoj komunikacijskih i socijalnih vještina, jačanje samopouzdanja, organizacijskih vještina, razumijevanje obiteljskih odnosa (npr. Ja kao važna karika, Moje mjesto u obitelji, Komunikacija - roditelj - dijete, Kad budem roditelj, ja ću ....) i drugih. Socijalnopedagoške intervencije usmjerene roditeljima i učiteljima također se provode u obliku individualnog i grupnog rada, pri čemu mogu sudjelovati u razgovorima i radionicama usmjerenima jačanju odgojnih potencijala, poticanju kvalitetnijih odnosa s djetetom/učenikom, razvoju odgojnih vještina i sl. (npr. Obitelj nije otok, Restitucija u praksi, Potrebe i želje).

Prijedlog Okvira za poticanje i prilagodbu iskustva učenja te vrednovanje postignuća djece $i$ učenika s teškoćama (2016., radna verzija dokumenta nastala u sklopu Cjelovite kurikularne reforme hrvatskog obrazovnog sustava) navodi da socijalni pedagog, među ostalim, pruža odgojno-obrazovnu podršku učenicima kod kojih postoji rizik za razvoj problema u ponašanju te osmišljava i provodi stručne intervencije za učenike s već razvijenim problemima u ponašanju, u svrhu njihova uspješnog udovoljavanja zahtjevima odgoja i obrazovanja te poticanja i podržavanja njihova zdravog razvoja. Pri tome:

- $\quad$ provodi procjenu potreba učenika, problema u ponašanju i potencijala koji proizlaze iz osobina samog učenika i njegovog okruženja

- razvija, provodi i vrednuje, s procjenom potreba usklađene i na dokazima učinkovitosti utemeljene individualne i grupne intervencije s učenicima

- predlaže drugim sudionicima odgojno-obrazovnog procesa različite oblike podrške učenicima

- provodi savjetodavni rad s učiteljima, roditeljima i drugim važnim odraslim osobama radi stvaranja uvjeta povoljnih za primjeren razvoj učenika.

Očigledno je, od socijalnih se pedagoga očekuje da implementiraju teorijske i znanstvene spoznaje koje osiguravaju postizanje očekivane dobrobiti korisnika socijalnopedagoških intervencija, a to je transformacija problema u ponašanju učenika u društveno prihvatljiva i individualno djelotvorna ponašanja. Riječ je o iznimno zahtjevnom i složenom procesu koji se u praksi razmjerno rijetko primjenjuje, kako zbog izrazite multidimenzionalnosti fenomenologije i etiologije problema u ponašanju, tako i zbog slabosti u sustavu intervencija koje nisu dovoljno diferencirane i usmjerene specifičnostima pojedinih korisnika (Bouillet, 2011). Praksa temeljena na pokazateljima uspješnosti podrazumijeva korištenje provjerenih vještina, tehnika i strategija u neposrednom kontaktu stručnjaka i korisnika, što dovodi do razvoja dokazano učinkovitih programa u formi organiziranih, slojevitih, multidisciplinarnih intervencija usmjerenih prema osobama sa složenim problemima (Bouillet, 2015a). Ukratko, radi se o planiranju praktičnog rada temeljem poznatih empirijskih saznanja koje osiguravaju postizanje željenih ishoda. Kada je riječ o socijalnopedagoškim intervencijama, praksa temeljena na dokazima uspješnosti dobrim dijelom ovisi o potrebama samih učenika, odnosno o teškoćama za koje je socijalni pedagog u suradnji sa samim učenikom procijenio da najviše ometaju njegovo uravnoteženo socijalno funkcioniranje. $U$ tom je kontekstu smisao procjene potreba učenika s problemima u ponašanju u njezinoj kvaliteti i primjerenosti intervencijskih potreba koje bi trebale dovesti do smanjivanja ili ublažavanja problema, odnosno do pozitivnih promjena koje svakoj osobi omogućavaju optimalnu uključenost u svakodnevni život u zajednici (Koller-Trbović, 
Mirosavljević, Jeđud Borić, 2013). S time su u vezi razvijeni različiti mjerni instrumenti (Koller-Trbović, Nikolić i Dugandžić, 2009; Žižak i Koller-Trbović, 2013 i dr.), ali su oni u pravilu primjereniji djeci i mladima koji već sudjeluju u nekom obliku socijalnopedagoškog tretmana u ustanovama specijaliziranima za rad s djecom i mladima s problemima u ponašanju.

Socijalnopedagoška praksa u osnovnim školama zahtijeva razvoj mjernih instrumenata koji će biti osjetljivi na potrebe učenika s problemima u ponašanju na način koji će osigurati njihovo pravovremeno uključivanje u intervenciju i omogućiti planiranje intervencije primjerene okruženju u kojem se provodi, a to su školske ustanove. Takav mjerni instrument usmjeren je sveobuhvatnoj procjeni snaga i slabosti djeteta i njegovog okruženja na koje se nadovezuje pružanje prikladne podrške konkretnom učeniku i osobama koje su za njegov razvoj iznimno važne (roditelji, učitelji, vršnjaci).

U ovom radu prikazan je proces nastajanja i standardizacije jednog takvog mjernog instrumenta za populaciju učenika osnovne škole u Republici Hrvatskoj, nazvanog Upitnik za procjenu potreba učenika za socijalnopedagoškim intervencijama - verzija za učenike.

\section{Kontekst istraživanja i pokusna primjena upitnika}

Istraživanje čiji su rezultati prikazani u ovom radu nastalo je u sklopu projekta Razvoj modela socijalnopedagoških intervencija u osnovnoj školi koji se uz podršku Agencije za odgoj i obrazovanje provodi od rujna 2015. godine s namjerom razvoja takvog modela socijalnopedagoške intervencije koji će omogućiti najbolju zaštitu prava učenika osnovnoškolske dobi s problemima u ponašanju, imajući pritom u vidu rasprostranjenost i fenomenologiju problema u ponašanju učenika, njihove potrebe za pravovremenim i stručnim prepoznavanjem te potrebu za intervencijom koja obuhvaća sve važne ekološke sustave i okruženja učenika (školu, obitelj, slobodno vrijeme, vršnjačke odnose i dr.). Projekt je nastao kao izraz potrebe socijalnih pedagoga zaposlenih u hrvatskim osnovnim školama za standardizacijom socijalnopedagoške prakse, kako bi svi učenici s problemima u ponašanju ostvarili svoje pravo na razvoj osobnosti, talenata i najviših potencijala duševnih i tjelesnih sposobnosti (Konvencija UN-a o pravima djeteta, 1990) i kako bi se pridonijelo ostvarenju Strategije obrazovanja, znanosti i tehnologije (2014) koja kao jedan od ciljeva predviđa osiguravanje cjelovitog sustava podrške učenicima s teškoćama (unutar odgojno-obrazovnih institucija i izvan njih).

Projekt je iniciran na stručnom skupu Analiza potreba i mogućnosti rane socijalnopedagoške intervencije koji je u organizaciji Agencije za odgoj i obrazovanje održan u Zagrebu u rujnu 2015. godine, gdje je formiran stručni tim za razvoj i vođenje rada na projektu4. Stručni tim razvio je projekt sa sljedećim specifičnim ciljevima:

- razvoj standardiziranih postupaka pravovremene i stručne identifikacije učenika s problemima u ponašanju

- razvoj modela socijalnopedagoške intervencije usklađene s identificiranim potrebama učenika s problemima u ponašanju te

\footnotetext{
4 Voditeljica stručnog tima je Alma Rovis Brandić, mag. prof. soc. pead. (Agencija za odgoj i obrazovanje), a članice su: prof. dr. sc. Dejana Bouillet (Učiteljski fakultet u Zagrebu), izv. prof. dr. sc. Valentina Kranželić (Edukacijsko-rehabilitacijski fakultet Sveučilišta u Zagrebu), Jelena Bićanić, prof. (OŠ Matka Laginje, Zagreb), Ana Ivančan, prof. (OŠ Ljudevita Modeca, Križevci), Ljiljana Samardžić, prof. (OŠ Nikole Tesle i OŠ Prečko, Zagreb), dr.sc. Nevenka Kišak Gverić, prof. (OŠ Grigora Viteza, Zagreb), Marija Sitar, prof. (OŠ Matije Gupca, Zagreb) i Željka Gomuzak Anić, prof. (OŠ Velika Mlaka, Velika Mlaka), sve socijalne pedagoginje.
} 
- razvoj sustava mjerenja učinkovitosti socijalnopedagoške intervencije s obzirom na postignute promjene ponašanja učenika i ekoloških čimbenika koji smanjuju rizik od budućih manifestacija problema u ponašanju korisnika intervencije.

U svrhu razvoja standardiziranih postupaka pravovremenog uključivanja učenika u socijalnopedagoške intervencije članice stručnog tima razvile su Upitnik za procjenu potreba učenika za socijalnopedagoškim intervencijama - verzija za učenike i roditelje. Upitnici su sadržavali set tvrdnji za samoprocjenu i procjenu odnosa učenika prema sebi, obitelji, razredniku, vršnjacima, obvezama, imovini i okruženju. Tvrdnje su organizirane u sedam skala, formiranih prema području procjene. Svaka je skala sadržavala 25 čestica, s izuzetkom skale za procjenu obiteljskih odnosa (verzija za učenike) jer su se neke u njoj sadržane tvrdnje odnosile na odnos s ocem i odnos s majkom (pa je tih tvrdnji bilo 40). Čestice su organizirane u obliku petostupanjskih skala Likertovog tipa pri čemu broj 1 označava "uopće nije točno", a broj 5 "potpuno je točno". Upitnici su tako široko postavljeni zbog potrebe sveobuhvatnog pristupa svim područjima socijalnopedagoških intervencija u školskom okruženju, a sadržavale su ujednačene čestice.

Obje verzije upitnika su provjerene pilot istraživanjem u osnovnim školama u kojima su zaposlene članice stručnog tima, a ovdje su prikazani rezultati koji se odnose na verziju za učenike. Upitnici su primijenjeni s učenicima trećih, petih i sedmih razreda osnovne škole, čiji su roditelji dali pisanu suglasnost za sudjelovanje učenika u istraživanju. Te su skupine učenika odabrane zbog razvojnih obilježja srednjeg djetinjstva i rane adolescencije, kao i zbog potrebe stjecanja uvida u mogući utjecaj tranzicije s razredne u predmetnu nastavu na ponašanje i potrebe učenika.

Istraživanje su provodili socijalni pedagozi na satovima razrednih odjela, uz primjereno informiranje i vođenje učenika i roditelja kroz proces popunjavanja upitnika, krajem prvog polugodišta školske godine 2015./2016. Radi osiguravanja anonimnosti učenika, a zbog potrebe naknadnog spajanja upitnika za učenike i upitnika za roditelje, upitnici su šifrirani.

U pilot istraživanju ukupno je sudjelovalo 350 učenika (51,4\% muškog i 48,6\% ženskog spola) u 6 osnovnih škola (tablica 1). Prosječna dob učenika je 10 godina i 8 mjeseci.

Tablica 1 Struktura uzorka pilot istraživanja prema školi i razredu kojeg učenik pohađa

\begin{tabular}{|l|c|c|c|c|}
\hline Osnovna škola & 3. razred & $\mathbf{5 . ~ r a z r e d}$ & $\mathbf{7}$. razred & UKUPNO \\
\hline Grigor Vitez & $15(35,7 \%)$ & $19(45,2 \%)$ & $8(19,0 \%)$ & $42(100 \%)$ \\
\hline Ljudevita Modeca & $23(11,3 \%)$ & $20(17,9 \%)$ & $22(7,2 \%)$ & $65(100 \%)$ \\
\hline Matije Gupca & $17(28,8 \%)$ & $21(35,6 \%)$ & $21(35,6 \%)$ & $59(100 \%)$ \\
\hline Matka Laginje & $15(46,9 \%)$ & $0(0,0 \%)$ & $17(53,1 \%)$ & $32(100 \%)$ \\
\hline Nikola Tesla & $20(48,8 \%)$ & $9(22,0 \%)$ & $12(29,3 \%)$ & $41(100 \%)$ \\
\hline Prečko & $23(39,7 \%)$ & $18(31,0 \%)$ & $17(29,3 \%)$ & $58(100 \%)$ \\
\hline Velika Mlaka & $20(37,7 \%)$ & $19(35,8 \%)$ & $14(26,4 \%)$ & $53(100 \%)$ \\
\hline UKUPNO & $\mathbf{1 3 3 ( 3 8 , 0 \% )}$ & $\mathbf{1 0 6}(\mathbf{3 0 , 3} \%)$ & $\mathbf{1 1 1}(\mathbf{3 1}, \mathbf{7} \%)$ & $\mathbf{3 5 0}(\mathbf{1 0 0} \%)$ \\
\hline
\end{tabular}

Svrha provedbe pilot-istraživanja odnosila se na pripremu standardizacije upitnika, odnosno provjeru njihovih mjernih karakteristika. U postupku obrade prikupljenih podataka, prvo je izvršena provjera varijabilnosti čestica i iz upitnika su izuzete sve čestice koje nisu udovoljavale kriteriju varijabilnosti. Drugim riječima, u upitnicima su ostale čestice u kojima je u svakoj kategoriji bilo 
zastupljeno najmanje $5 \%$ odgovora ispitanika. Ovom se prilikom nije obraćala pozornost na normalnost distribucije jer je predmet istraživanja usmjeren manjinskoj skupini učenika, pa bi se takvim pristupom mogle preuranjeno izdvojiti čestice koje mogu biti važne za procjenu njihovih potreba.

U drugom su koraku provjeravane pouzdanosti svake pojedinačne skale. $U$ tu je svrhu izračunat ukupan rezultat ispitanika na svakoj skali i utvrđen je Pearsonov koeficijent korelacije svake čestice $s$ tim rezultatom. $U$ upitniku su zadržane čestice koje su s ukupnim rezultatom na skali bile statistički značajno povezane $(p=, 000)$. U trećem je koraku provjeravana pouzdanost skale, računanjem Cronbach Alpha koeficijenata. Rezultati primijenjenih analiza prikazani su u tablici 2.

Tablica 2 Broj početnih i preostalih čestica skala samoprocjene intervencijskih potreba učenika i pripadajući Cronbach Alpha koeficijenti Upitnika za procjenu intervencijskih potreba učenika - verzija za učenike

\begin{tabular}{|l|c|c|c|c|}
\hline Skala & Početne čestice & $\begin{array}{c}\text { Preostale čestice u } \\
\text { prvom koraku }\end{array}$ & $\begin{array}{c}\text { Preostale čestice u } \\
\text { drugom koraku }\end{array}$ & Cronbach Alpha \\
\hline Odnos prema sebi & 25 & 21 & 16 &, 608 \\
\hline Odnos prema obitelji & 40 & 17 & 14 &, 798 \\
\hline Odnos prema razredniku & 25 & 12 & 21 & \multirow{2}{*}{, 687} \\
\hline Odnos prema obvezama & 25 & 13 & 13 &, 735 \\
\hline Odnos prema vršnjacima & 25 & 12 & 14 &, 560 \\
\hline Odnos prema imovini i okruženju & 25 & 10 & $\mathbf{7 8}$ &, $\mathbf{8 3 9}$ \\
\hline UKUPNO & $\mathbf{1 6 5}$ & $\mathbf{8 5}$ & & \\
\hline
\end{tabular}

Kao što je iz podataka prikazanih u tablici 2 vidljivo, u nekoliko skala mnoge čestice nisu prošle provjeru varijabilnosti jer su slabo diskriminirale ispitanike s obzirom na predmet mjerenja. Čestice iz tih skala su ujedinjene u jednu skalu pa konačna verzija Upitnika sadrži 5 skala (Odnos prema sebi, Odnos prema obitelji, Odnos prema školi, Odnos prema vršnjacima te Odnos prema imovini i okruženju). Skala Odnos prema školi sadrži čestice koje su prvobitno činile skale Odnos prema razredniku i Odnos prema obvezama.

\section{Cilj, zadaci i hipoteze istraživanja}

Cilj istraživanja koje je uslijedilo nakon pilot-istraživanja i utvrđivanja mjernih karakteristika razvijenih instrumenata jest razviti mjerni instrument za pravovremenu identifikaciju problema u ponašanju učenika osnovnih škola, temeljem samoprocjene učenika, kako bi se osigurali preduvjeti za kreiranje i evaluaciju socijalnopedagoških intervencija u školskom okruženju, a to su: (a) standardizirani postupak identifikacije učenika s problemima u ponašanju te (b) utvrđivanje potreba učenika za socijalnopedagoškim intervencijama. Razvojem takvih mjernih instrumenata pridonosi se razvoju prakse temeljene na pokazateljima uspješnosti u socijalnopedagoškoj djelatnosti, budući da njegov sadržaj omogućuje i praćenje promjena u ispitivanim područjima socijalnopedagoških intervencija, odnosno mjerenje potreba učenika prije, tijekom i nakon uključivanja u različite socijalnopedagoške i druge intervencije. 
Iz tako formuliranog cilja proizlaze sljedeći istraživački zadaci:

- konstrukcija mjernog instrumenta za procjenu potreba učenika osnovnih škola za socijalnopedagoškom intervencijom, temeljem samoprocjena učenika (Upitnika za procjenu potreba učenika za socijalnopedagoškim intervencijama - verzije za učenike)

- utvrđivanje normi za identifikaciju učenika s problemima u ponašanju

- provjera utvrđenih normi s obzirom na dob i spol učenika

- utvrđivanje udjela učenika s problemima u ponašanju u populaciji učenika osnovnoškolske dobi u Hrvatskoj.

Istraživanjem se provjerava opća hipoteza kojom se pretpostavlja da Upitnik za procjenu potreba učenika za socijalnopedagoškim intervencijama - verzija za učenike primjereno razlikuje učenike s problemima u ponašanju od ostalih učenika, pri čemu norme za procjenu određenih kategorija učenika ovise o njihovom spolu i dobi. Također je pretpostavljeno da će udio učenika s problemima u ponašanju u populaciji učenika osnovnoškolske dobi biti u skladu s ranije provedenim istraživanjima, odnosno do 15\% (Bouillet, 2015b; Pavin Ivanec, 2015). Budući da rizična ponašanja ponajprije zahtijevaju reakciju obitelji i drugih osoba iz djetetovih redovnih životnih sredina (npr. učitelja ili pedagoga), mjerni je instrument usmjeren identifikaciji učenika s teškoćama u ponašanju i poremećajima u ponašanju.

\section{Metode istraživanja}

\section{Sudionici istraživanja}

Istraživanje je provedeno na uzorku 3301 učenika trećih, petih i sedmih razreda u 43 osnovne škole u Republici Hrvatskoj. Iz svake je škole u istraživanju sudjelovao najmanje jedan razredni odjel za svaki razred.

Radi se o školama iz 13 županija u kojima su zaposleni socijalni pedagozi, a koji su dobrovoljno pristali sudjelovati u istraživanju ${ }^{5}$. Prema podacima Državnog zavoda za statistiku, u Hrvatskoj djeluje 860 matičnih škola, u kojima se školuje 119.441 učenika trećih, petih i sedmih razreda (Statističko priopćenje: Osnovne škole - kraj šk. god. 2014./2015. i početak šk. god. 2015./2016.). Prema tome, uzorak istraživanja čini 5\% osnovnih škola u Hrvatskoj, odnosno 2,76\% svih učenika trećih, petih i sedmih razreda osnovnih škola. Ipak, budući da su socijalni pedagozi zaposleni u razmjeno malom broju škola u Hrvatskoj (u svega 15\% škola), radi se o uzorku koji je u odnosu na ukupan broj škola u Hrvatskoj prigodan.

U uzorku je 50,6\% učenika i 49,4\% učenica. Među njima je 31,4\% polaznika trećeg, 35,5\% petog i 33,1\% polaznika sedmog razreda. Prosječna dob učenika je 11 godina i 2 mjeseca. Većina učenika $(59,2 \%)$ prethodne je školske godine postigla odličan uspjeh, trećina $(32,2 \%)$ vrlo dobar uspjeh, dok je ocjenom dobar ocijenjeno 8,1\% učenika. 14 ili 0,4\% učenika prethodni je razred završilo dovoljnom ocjenom, a dva su učenika $(0,1 \%)$ ponavljala razred.

$\overline{5}$ Podaci o školama koje su sudjelovale u istraživanju dostupne su kod autorice rada, a ovdje nisu prikazane zbog njihovog opsega. 
Radi provjere valjanosti upitnika, socijalni pedagozi su za svakog učenika neovisno o rezultatima istraživanja upisali radi li se o učeniku koji prema njihovim stručnim saznanjima (proizašlih iz neposrednog rada u školi) manifestira ili ne manifestira probleme u ponašanju. Prema tom kriteriju, u uzorku je 2.826 ili 85,6\% učenika koji ne manifestiraju te 475 odnosno $14,4 \%$ učenika koji manifestiraju probleme u ponašanju, što je u skladu s poznatim istraživanjima o prevalenciji problema u ponašanju učenika osnovnoškolske dobi, uzmu li se u obzir učenici s već izraženim problemima u ponašanju (odnosno, isključujući učenike rizičnog ponašanja).

\section{Prikupljanje podataka i mjerni instrumenti}

Za sve sudionike istraživanja dobivene su pisane suglasnosti njihovih roditelja za sudjelovanje u istraživanju. Odaziv na sudjelovanje u istraživanju je varirao od škole do škole, ali je u svakoj školi bio veći od $90 \%$. Podatke su prikupljali i upisivali u bazu podataka socijalni pedagozi koji su također dobrovoljno pristali na sudjelovanje u istraživanju, svatko za svoju školu. Oni su posebno educirani za primjenu Upitnika i unos podataka na stručnom skupu socijalnih pedagoga koji se u organizaciji Agencije za odgoj i obrazovanje održao 23. veljače 2016. godine u Zagrebu.

Primjerena informiranost o svrsi istraživanja postignuta je predstavljanjem istraživanja od strane socijalnih pedagoga učenicima na satovima razrednih odjela, a roditeljima na roditeljskim sastancima. U tu je svrhu pripremljena posebna prezentacija koju su socijalni pedagozi koristili u svakoj školi. Anonimnost sudionika istraživanja postignuta je naknadnim šifriranjem upitnika, prema unaprijed utvrđenim kodovima.

Učenici su popunjavali Upitnik za procjenu potreba učenika za socijalnopedagoškim intervencijama - verzija za učenike koji je konstruiran temeljem rezultata pilot istraživanja i sadržavao je 78 čestica grupiranih u pet skala. Učenici su upitnike popunjavali tijekom jednog školskog sata, uz stručno vođenje socijalnih pedagoga.

\section{Obrada podataka}

U svrhu postizanja sadržajne valjanosti mjernih instrumenata, u njihovu je izradu uključen veći broj stručnjaka (socijalnih pedagoga). Radi utvrđivanja njegove konstrukcijske valjanosti, provedena je faktorska analiza upitnika, metodom glavnih komponenti. Kako bi se maksimaliziralo razlikovanje određenih pretpostavljenih aspekata potreba učenika, provedena je Varimax rotacija. Utvrđivanje kriterijske valjanosti upitnika temeljilo se na uvođenju neovisnog kriterija, a to je utvrđivanje problema u ponašanju učenika drugim metodama, neovisno o rezultatu postignutom na Upitniku6 ${ }^{6}$. Također je iznalažena korelacija pojedinih čestica s ukupnim rezultatom ispitanika na Upitniku. Pouzdanost mjernog instrumenta provjeravana je utvrđivanjem Cronbach Alpha koeficijenata, a osjetljivost pomoću provjere statističke značajnosti razlika među učenicima s i bez problema u ponašanju, upotrebom t-testa za nezavisne uzorke, na faktorima ekstrahiranima faktorskom analizom.

Norme su definirane temeljem precentila, odnosno rezultata učenika na faktorima pojedinih upitnika, s obzirom na njihov spol i dob. One su naknadno provjerene dvo-stupanjskom klaster

6 Radi se o već objašnjenoj informaciji koja se temelji na neposrednom iskustvu socijalnih pedagoga u odnosu s konkretnim učenicima, budući da s njima neposredno rade, provodeći socijalnopedagoške intervencije. 
Dejana Bouillet: Procjena potreba učenika osnovne škole u svrhu planiranja socijalnopedagoških intervencija...

analizom, izračunavanjem Peasonovog koeficijenta korelacije utvrđenih grupa učenika s njihovim neovisno procijenjenim problemima u ponašanju i statističke značajnosti t-testa za neovisne uzorke.

\section{Rezultati istraživanja}

Svrha je svakog mjernog instrumenta da sa što je moguće manjim brojem čestica opiše ispitanika temeljem obilježja kojem je instrument namijenjen. Konstrukciji Upitnika za procjenu potreba učenika za socijalnopedagoškim intervencijama - verzije za učenike pristupilo se vrlo široko, kako bi se izbjeglo previđanje ili zanemarivanje nekih aspekata problema u ponašanju učenika osnovnoškolske dobi pa je sadržavao veliki broj varijabli (78). Stoga je postupak standardizacije upitnika bio usmjeren daljnjem značajnom smanjivanju broja čestica, uz očuvanje mjernih karakteristika upitnika.

U prvom je koraku provjeravana distribucija čestica, temeljem mjera asimetrije (Skewness) i zakrivljenosti (Kurtosis) distribucije, imajući u vidu kriterij prihvatljivosti normalnosti distribucije ako se koeficijenti kreću između -2 i 2. (George i Mallery, 2010). Temeljem tog kriterija iz upitnika je izuzeta čestica Moj razrednik me kažnjava bez razloga (Skewness = 2,498; Kurtosis = 5,579). Cronbach Alpha koeficijent nakon tog koraka (sa 77 čestica) iznosio je ,862.

$\mathrm{U}$ drugom je koraku proveden t-test nezavisnih uzorka, gdje su učenici razvrstani temeljem neovisnog kriterija, odnosno ranije utvrđenog problema u ponašanju, kako bi se osigurala osjetljivost upitnika na predmet mjerenja. Iz upitnika su izuzete sve varijable čija je statistička značajnost t-testa bila veća od 0,050, njih 7 (tablica 3). Nakon njihovog izuzimanja iz upitnika, Cronbach Alpha koeficijent je porastao na ,871 (70 čestica).

Tablica 3 Čestice koje su iz Upitnika izuzete zbog slabe osjetljivosti na kriterij problema u ponašanju učenika (vrijednost $i$ značajnost $t$-testa)

\begin{tabular}{|l|c|c|}
\hline Čestica & Vrijednost t-testa & Razina značajnosti (p) \\
\hline Volim biti sam/a kada sam tužan/na. &, 776 &, 378 \\
\hline Volim biti uredan/na. & 2,146 &, 143 \\
\hline Bojim se svog razrednika. &, 332 &, 564 \\
\hline Imam puno više stvari nego što mi treba. &, 028 &, 866 \\
\hline Kada želim nešto što mi ne pripada, zamolim vlasnika da mi posudi tu stvar. &, 012 &, 914 \\
\hline Volim kupovati različite stvari. & 1,892 &, 169 \\
\hline Znam gdje u mojoj kući stoji novac. &, 319 &, 572 \\
\hline
\end{tabular}

U sljedećem koraku je izračunat ukupan rezultat učenika na svim česticama Upitnika, kako bi se ustanovila statistička značajnost korelacija pojedinih čestica s ukupnim rezultatom, izračunavanjem Pearsonovog koeficijenta korelacije. U tom su koraku izuzete 3 čestice čija je statistička značajnost korelacija bila manja od ,050. To su čestice: Često kupim nešto što mi ne treba (Coef corr $=, 026)$, Često razmišljam o materijalnim stvarima (Coef corr $=, 042)$ i Teško se odričem i teško odustajem od nečeg što želim imati (Coef corr $=, 028$ ). Cronbach Apha koeficijent Upitnika nakon ovog koraka porastao je na,881 (ukupno 67 čestica).

Potom je provedena faktorska analiza. Prema Guttman-Kaiserovu kriteriju izdvojeno je 17 faktora koji su objašnjavali 53,15\% zajedničke varijance. Analizom scree plot dijagrama te sadržajnom analizom ekstrahiranih faktora iz upitnika i njihovom interpretabilnosti, iz upitnika su izdvojene 
čestice koje se nisu dobro pozicionirale na faktore. Radi se o česticama koje imaju podjednaka višestruka faktorska zasićenja, koje u sklopu faktora nisu sadržajno jednoznačno interpretabilne i čija su maksimalna faktorska zasićenja manja od 0,40 (Tabachnik i Fidell, 2001).

U ovom je koraku izdvojeno dodatnih 14 čestica, a Cronbach Apha koeficijent Upitnika nakon ovog koraka je ostao isti (,881, ukupno 53 čestice). Radi se o sljedećim česticama: Siguran/na sam i samouvjeren/a, U neugodnim se situacijama povlačim, Volim biti u centru pažnje, U mojoj obitelji nesporazume rješavamo dogovorom, Poštujem školska pravila, Bavim se izvanškolskim aktivnostima, Imam dovoljno vremena za izvanškolske aktivnosti, Znam raspored sati napamet, Moji prijatelji poštuju školska pravila, Događa mi se da uzmem tuđu stvar bez znanja drugih, Kada imam novaca, volim odmah sve potrošiti, Moji vršnjaci imaju puno više stvari od mene, Rado dijelim s drugima svoje stvari i Redovito dobivam džeparac.

Potom je ponovljena faktorska analiza s 53 čestice, nakon koje je prema istom kriteriju dodatno izdvojeno još 11 čestica (Mogu ostati smiren/a i kada sam ljut/a, Svadljiv/a sam, Učim iz svojih pogrešaka, Sudjelujem u donošenju važnih obiteljskih odluka, Moj razrednikje blag i popustljiv, Drugi učenici me izbjegavaju, Važno mi je da moji vršnjaci o meni imaju dobro mišljenje, Nesporazume s vršnjacima rješavam na miran način, Prijatelji me mogu nagovoriti na nešto što ne želim, Kad nađem neku stvar, a ne znam čija je, tražim vlasnika i Uporan sam da dođem do stvari koju želim, ali pri tome brinem o drugima).

Konačna faktorska analiza izvršena je na 42 čestice. Ona je rezultirala s 9 faktora koji objašnjavaju 53,15\% zajedničke varijance (jednako kao i prva faktorska analiza koja je provedena na znatno većem broju čestica). Cronbach Alpha koeficijent unutarnje konzistencije upitnika iznosi ,894. Utvrđeno je da su potrebni preduvjeti za faktorizaciju zadovoljeni ( $K M O=, 890$; Bartlettov test specificeta $=35327,614, \mathrm{df}=1035, \mathrm{p}=, 000)$. Vrijednosti karakterističnih korijena, postotak objašnjene varijance, pouzdanost i struktura svakog faktora prikazani su u tablici 4 .

\section{Tablica 4 Vrijednosti karakterističnih korijena, postotak objašnjene varijance, pouzdanost i struktura faktora Upitnika za procjenu potreba učenika za socijalnopedagoškim intervencijama - verzija za učenike}

\begin{tabular}{|l|c|}
\hline FAKTOR PROCJENE ODNOSA S VRŠNJACIMA (1) & Koeficijenti \\
\hline Mislim da većina učenika o meni ima dobro mišljenje. &, 643 \\
\hline Prijatelji me saslušaju kad imam neki problem. &, 600 \\
\hline S prijateljima iz razreda družim se i izvan škole. &, 578 \\
\hline Vjerujem svojim prijateljima. &, 632 \\
\hline Za vrijeme odmora, družim se s mnogim učenicima. &, 604 \\
\hline Zadovoljan/na sam brojem prijatelja koje imam. &, 556 \\
\hline Drugi su učenici prema meni pažljivi. &, 597 \\
\hline Karakteristični korijen & $\mathbf{8 , 7 0 3}$ \\
\hline Postotak objašnjene varijance & 19,434 \\
\hline Cronbach Apha &, 762 \\
\hline FAKTOR PROCJENE ODNOSA PREMA OBRAZOVANJU (2) &, 699 \\
\hline Moj školski uspjeh odgovara uloženom trudu i sposobnostima. &, 423 \\
\hline Često se javljam da odgovorim na pitanja učitelja za vrijeme nastave. &, 727 \\
\hline Zadovoljan/na sam uspjehom koji postižem u školi. &, 618 \\
\hline Kod kuće redovito učim i pišem zadaće. & \\
\hline
\end{tabular}


Dejana Bouillet: Procjena potreba učenika osnovne škole u svrhu planiranja socijalnopedagoških intervencija...

\begin{tabular}{|c|c|}
\hline Mislim da moj školski uspjeh dobro odražava moj trud i zalaganje. &, 752 \\
\hline Karakteristični korijen & 2,498 \\
\hline Postotak objašnjene varijance & 5,945 \\
\hline Cronbach Apha & ,764 \\
\hline \multicolumn{2}{|l|}{ FAKTOR PROCJENE ODNOSA PREMA OBVEZAMA (3) } \\
\hline Rado idem u školu. & ,457 \\
\hline Sudjelujem u obavljanju kućanskih poslova. & 687 \\
\hline Svoj radni prostor kod kuće i u školi održavam urednim i čistim. & ,648 \\
\hline Uspješno organiziram vrijeme za učenje. & ,491 \\
\hline Kada se moji prijatelji posvađaju, pomažem im da se pomire. & 460 \\
\hline Karakteristični korijen & 2,158 \\
\hline Postotak objašnjene varijance & 5,207 \\
\hline Cronbach Apha & 638 \\
\hline \multicolumn{2}{|l|}{ FAKTOR PROCJENE ODNOSA S RODITELJIMA (4) } \\
\hline Kada neki problem ne mogu riješiti sam/a, tražim pomoć majke. & ,616 \\
\hline Pred svojom majkom nemam tajni. & ,645 \\
\hline S mojom majkom mogu otvoreno razgovarati o bilo čemu. & 675 \\
\hline Kada neki problem ne mogu riješiti sam/a, tražim pomoć oca. & ,681 \\
\hline Pred svojim ocem nemam tajni. & ,700 \\
\hline S mojim ocem mogu otvoreno razgovarati o bilo čemu. & ,781 \\
\hline Karakteristični korijen & 1,926 \\
\hline Postotak objašnjene varijance & 4,702 \\
\hline Cronbach Apha & ,677 \\
\hline \multicolumn{2}{|l|}{ FAKTOR PROCJENE RAZINE RODITELJSKE PODRŠKE (5) } \\
\hline Moja majka je uz mene i kad učinim nešto loše. &, 614 \\
\hline Moja majka me razumije i prihvaća i kad radim nešto što je neprihvatljivo. & 826 \\
\hline Moj otac je uz mene i kad učinim nešto loše. & 603 \\
\hline Moj otac me razumije i prihvaća i kad radim nešto što je neprihvatljivo. & 798 \\
\hline Karakteristični korijen & 1,660 \\
\hline Postotak objašnjene varijance & 4,124 \\
\hline Cronbach Apha & ,767 \\
\hline \multicolumn{2}{|l|}{ FAKTOR PROCJENE OTVORENOSTI U KOMUNIKACIJI I INTERESIMA (6) } \\
\hline Bez teškoća govorim pred razredom i većom grupom ljudi. & 495 \\
\hline Izražavam svoje mišljenje i kada je ono različito od mišljenja ostalih. & ,639 \\
\hline Mogu izreći svoje mišljenje i kad je drugačije od mišljenja razrednika. & ,636 \\
\hline S lakoćom postavljam pitanja razredniku za vrijeme nastave. & 606 \\
\hline Imam mnoge interese koji nisu povezani sa školom. & 436 \\
\hline Karakteristični korijen & 1,358 \\
\hline Postotak objašnjene varijance & 3,911 \\
\hline Cronbach Apha & 631 \\
\hline \multicolumn{2}{|l|}{ FAKTOR PROCJENE ODNOSA S RAZREDNIKOM (7) } \\
\hline Kada neki problem ne mogu riješiti sam/a, tražim pomoć razrednika. & 406 \\
\hline Sa svojim razrednikom mogu razgovarati kad god za tim imam potrebu. &, 594 \\
\hline Udovoljavam zahtjevima svog razrednika bez prigovora. & ,538 \\
\hline Vjerujem da moj razrednik o meni ima dobro mišljenje. & 609 \\
\hline Karakteristični korijen & 1,873 \\
\hline Postotak objašnjene varijance & 2,952 \\
\hline Cronbach Apha & 619 \\
\hline FAKTOR PROCJENE ZADOVOLJSTVA SOBOM (8) & \\
\hline
\end{tabular}


Kriminologija i socijalna integracija Vol. 24 Br. 2. 2016.

\begin{tabular}{|l|c|}
\hline Ponosan sam na sebe i svoje postupke. &, 494 \\
\hline Zadovoljan/na sam sobom takav/takva kakav/kakva sam. &, 783 \\
\hline Zadovoljan/na sam svojim izgledom. &, 767 \\
\hline Karakteristični korijen & $\mathbf{1 , 2 6 0}$ \\
\hline Postotak objašnjene varijance & 3,254 \\
\hline Cronbach Apha &, 660 \\
\hline FAKTOR PROCJENE PERMISIVNOSTI U ODGOJU (9) &, 778 \\
\hline Moja majka je prema meni blaga i popustljiva. &, 723 \\
\hline Moj otac je prema meni blag i popustljiv. &, 667 \\
\hline Moj razrednik je prema meni blag i popustljiv. & $\mathbf{1 , 1 9 3}$ \\
\hline Karakteristični korijen & 3,109 \\
\hline Postotak objašnjene varijance &, $\mathbf{6 3 5}$ \\
\hline Cronbach Apha & \\
\hline
\end{tabular}

Kao što iz podataka prikazanih u tablici 6 proizlazi, početno široko postavljene skupine potreba učenika su se faktorskom analizom specificirale, pri čemu se skala odnosa prema sebi podijelila u dva faktora (otvorenost u komunikaciji i interesima te zadovoljstvo sobom), skala odnosa prema školi u tri faktora (odnos prema obrazovanju, odnos prema obvezama i odnos prema razredniku), kao i skala odnosa prema obitelji (odnos s roditeljima, razina roditeljske podrške i permisivnost u odgoju). Skala odnosa s vršnjacima ostala je nepodijeljena, a čestice skale odnosa prema imovini i okruženju nisu prošle provjere metrijskih karakteristika Upitnika. Neke čestice su iz početnih skala promijenile svoju poziciju. Ukupno promatrajući, formirani faktori zadovoljavaju statističke kriterije pouzdanosti pa se u daljnjim analizama koristi ukupan rezultat učenika na svakom pojedinom faktoru.

U tablici 5 prikazana je deskriptivna statistika za formirane faktore Upitnika.

Tablica 5 Deskriptivna statistika faktora Upitnika za procjenu potreba učenika za socijalnopedagoškim intervencijama - verzija za učenike

\begin{tabular}{|c|c|c|c|c|c|c|c|}
\hline Faktor & Rang & Minimum & Maksimum & $\begin{array}{c}\text { Ar. } \\
\text { sredina }\end{array}$ & $\begin{array}{c}\text { Standardna } \\
\text { devijacija }\end{array}$ & Skweness & Kustosis \\
\hline Odnos s vršnjacima (1) & 28 & 7 & 35 & 29,45 & 4,30 & $-1,338$ & 2,591 \\
\hline Odnos prema obrazovanju (2) & 20 & 5 & 25 & 20,33 & 3,75 &,- 898 & 458 \\
\hline Odnos prema obvezama (3) & 16 & 4 & 20 & 15,75 & 3,15 &,- 733 & 179 \\
\hline Odnos s roditeljima (4) & 24 & 6 & 30 & 24,88 & 4,06 & $-1,031$ & 1,149 \\
\hline Razina roditeljske podrške (5) & 16 & 4 & 20 & 15,79 & 3,65 &,- 853 &, 231 \\
\hline $\begin{array}{l}\text { Otvorenost u komunikaciji i } \\
\text { interesima (6) }\end{array}$ & 24 & 6 & 30 & 23,41 & 4,07 &,- 694 &, 527 \\
\hline Odnos s razrednikom (7) & 16 & 4 & 20 & 16,01 & 2,95 &,- 931 & 1,092 \\
\hline Zadovoljstvo sobom (8) & 12 & 3 & 15 & 12,88 & 2,19 & $-1,439$ & 2,394 \\
\hline Permisivnost u odgoju (9) & 12 & 3 & 15 & 11,39 & 2,63 &,- 591 &,- 100 \\
\hline
\end{tabular}

T-testom i Pearsnovom korelacijom je utvrđeno da se grupe učenika, prema neovisno utvrđenom kriteriju problema u ponašanju, međusobno statistički značajno razlikuju na svim faktorima, te pripadnost tako formiranoj grupi istodobno statistički značajno korelira s faktorima (tablica 6). 
Dejana Bouillet: Procjena potreba učenika osnovne škole u svrhu planiranja socijalnopedagoških intervencija...

Tablica 6 Statistička značajnost i vrijednosti t-testa i Pearsonovog koeficijenta korelacija faktora Upitnika za procjenu potreba učenika za socijalnopedagoškim intervencijama - verzija za učenike, prema problemima u ponašanju učenika

\begin{tabular}{|l|c|c|c|c|}
\hline Faktor & T-test & Značajnost & Pearsonov koeficijent & Značajnost \\
\hline Odnos s vršnjacima (1) & 16,941 &, 000 &, 078 &, 000 \\
\hline Odnos prema obrazovanju (2) & 43,858 &, 000 &, 128 &, 000 \\
\hline Odnos prema obvezama (3) & 14,880 &, 000 &, 028 &, 000 \\
\hline Odnos s roditeljima (4) & 23,531 &, 000 &, 095 &, 000 \\
\hline Razina roditeljske podrške (5) & 15,427 &, 000 &, 042 &, 019 \\
\hline Otvorenost u komunikaciji i interesima (6) & 16,715 &, 000 &, 067 &, 000 \\
\hline Odnos s razrednikom (7) & 12,230 &, 000 &, 065 &, 000 \\
\hline Zadovoljstvo sobom (8) & 50,230 &, 000 &, 105 &, 000 \\
\hline Permisivnost u odgoju (9) & 2,872 &, 000 &, 049 &, 009 \\
\hline
\end{tabular}

Sukladno precentilima koji su izračunati za ukupan uzorak te za subuzorke muških i ženskih ispitanika, odnosno učenike trećih, petih i sedmih razreda Učenici su svrstani u tri grupe - učenike s poremećajima u ponašanju (prvi precentil), učenike s teškoćama u ponašanju (drugi precentil) i ostale učenike koji ne iskazuju teškoće i poremećaje u ponašanju (treći do sedmi precentil). Precentili su prikazani u tablici 7.

Tablica 7 Precentili rezultata postignutih na faktorima Upitnik za procjenu potreba učenika za socijalnopedagoškim intervencijama - verzija za učenike, prema problemima u ponašanju učenika

\begin{tabular}{|c|c|c|c|c|c|c|}
\hline \multicolumn{7}{|c|}{ Odnos s vršnjacima (1) } \\
\hline Precentili & Uk. & M & $\check{z}$ & 3. $\mathbf{R}$. & 5. $R$. & 7.R. \\
\hline 5 & 21,0 & 21,0 & 21,0 & 21,25 & 21,0 & 21,0 \\
\hline 10 & 24,0 & 24,0 & 24,0 & 24,0 & 24,0 & 23,0 \\
\hline 25 & 27,0 & 27,0 & 28,0 & 27,0 & 28,0 & 27,0 \\
\hline 50 & 30,0 & 30,0 & 31,0 & 30,0 & 31,0 & 30,0 \\
\hline 75 & 33,0 & 32,0 & 33,0 & 33,0 & 33,0 & 32,0 \\
\hline 90 & 34,0 & 34,0 & 34,0 & 35,0 & 34,0 & 34,0 \\
\hline 95 & 35,0 & 35,0 & 35,0 & 35,0 & 35,0 & 34,0 \\
\hline \multicolumn{7}{|c|}{ Odnos prema obrazovanju (2) } \\
\hline Precentili & Uk. & $\mathbf{M}$ & ž & 3. $R$. & 5. R. & 7.R. \\
\hline 5 & 13,0 & 13,0 & 14,0 & 16,0 & 14,0 & 12,0 \\
\hline 10 & 15,0 & 15,0 & 16,0 & 17,0 & 16,0 & 13,0 \\
\hline 25 & 18,0 & 18,0 & 19,0 & 19,0 & 19,0 & 17,0 \\
\hline 50 & 21,0 & 21,0 & 22,0 & 22,0 & 22,0 & 20,0 \\
\hline 75 & 23,0 & 23,0 & 24,0 & 24,0 & 24,0 & 23,0 \\
\hline 90 & 25,0 & 25,0 & 25,0 & 25,0 & 25,0 & 24,0 \\
\hline 95 & 25,0 & 25,0 & 25,0 & 25,0 & 25,0 & 25,0 \\
\hline \multicolumn{7}{|c|}{ Odnos prema obvezama (3) } \\
\hline Precentili & Uk. & $\mathbf{M}$ & ž & 3. $\mathbf{R}$. & 5. $\mathbf{R}$. & 7.R. \\
\hline 5 & 10,0 & 9,0 & 11,0 & 10,0 & 11,0 & 9,0 \\
\hline 10 & 11,0 & 11,0 & 12,0 & 12,0 & 12,0 & 11,0 \\
\hline 25 & 14,0 & 13,0 & 15,0 & 15,0 & 14,0 & 13,0 \\
\hline 50 & 16,0 & 16,0 & 17,0 & 17,0 & 16,0 & 15,0 \\
\hline 75 & 18,0 & 18,0 & 19,0 & 19,0 & 18,0 & 17,0 \\
\hline 90 & 20,0 & 19,0 & 20,0 & 20,0 & 20,0 & 18,0 \\
\hline
\end{tabular}


Kriminologija i socijalna integracija Vol. 24 Br. 2. 2016.

\begin{tabular}{|c|c|c|c|c|c|c|}
\hline 95 & 20,0 & 20,0 & 20,0 & 20,0 & 20,0 & 19,0 \\
\hline \multicolumn{7}{|c|}{ Odnos s roditeljima (4) } \\
\hline Precentili & Uk. & M & $\check{z}$ & 3. $R$. & 5. $R$. & 7.R. \\
\hline 5 & 17,4 & 17,0 & 18,0 & 18,0 & 18,0 & 16,0 \\
\hline 10 & 19,8 & 19,0 & 20,0 & 20,0 & 20,0 & 18,0 \\
\hline 25 & 23,0 & 22,0 & 23,0 & 24,0 & 23,0 & 21,0 \\
\hline 50 & 26,0 & 26,0 & 26,0 & 26,0 & 26,0 & 24,0 \\
\hline 75 & 28,0 & 28,0 & 28,0 & 28,0 & 28,0 & 27,0 \\
\hline 90 & 30,0 & 30,0 & 29,0 & 30,0 & 30,0 & 29,0 \\
\hline 95 & 30,0 & 30,0 & 30,0 & 30,0 & 30,0 & 30,0 \\
\hline \multicolumn{7}{|c|}{ Razina roditeljske podrške (5) } \\
\hline Precentili & Uk. & M & $\check{z}$ & 3. $R$. & 5. $R$. & 7.R. \\
\hline 5 & 9,0 & 8,0 & 10,0 & 8,0 & 9,0 & 8,0 \\
\hline 10 & 11,0 & 10,0 & 12,0 & 11,0 & 11,0 & 11,0 \\
\hline 25 & 13,0 & 13,0 & 14,0 & 14,0 & 14,0 & 13,0 \\
\hline 50 & 16,0 & 16,0 & 17,0 & 16,0 & 17,0 & 16,0 \\
\hline 75 & 19,0 & 18,0 & 19,0 & 19,0 & 19,0 & 18,0 \\
\hline 90 & 20,0 & 20,0 & 20,0 & 20,0 & 20,0 & 20,0 \\
\hline 95 & 20,0 & 20,0 & 20,0 & 20,0 & 20,0 & 20,0 \\
\hline \multicolumn{7}{|c|}{ Otvorenost u komunikaciji i interesima (6) } \\
\hline Precentili & Uk. & M & $\check{z}$ & 3. $\mathbf{R}$. & 5. R. & 7.R. \\
\hline 5 & 16,0 & 16,0 & 16,0 & 16,0 & 16,0 & 17,0 \\
\hline 10 & 18,0 & 18,0 & 18,0 & 18,0 & 19,0 & 19,0 \\
\hline 25 & 21,0 & 21,0 & 21,0 & 20,0 & 21,0 & 22,0 \\
\hline 50 & 24,0 & 24,0 & 24,0 & 23,0 & 24,0 & 24,0 \\
\hline 75 & 26,0 & 26,0 & 27,0 & 26,0 & 27,0 & 27,0 \\
\hline 90 & 28,0 & 28,0 & 28,0 & 28,0 & 28,0 & 28,0 \\
\hline 95 & 29,0 & 29,0 & 29,0 & 29,0 & 29,0 & 29,0 \\
\hline \multicolumn{7}{|c|}{ Odnos s razrednikom (7) } \\
\hline Precentili & Uk. & M & $\check{z}$ & 3. $R$. & 5. $R$. & 7.R. \\
\hline 5 & 11,0 & 10,0 & 12,0 & 12,0 & 12,0 & 9,0 \\
\hline 10 & 12,0 & 12,0 & 13,0 & 13,0 & 13,0 & 11,0 \\
\hline 25 & 14,0 & 14,0 & 15,0 & 15,0 & 15,0 & 13,0 \\
\hline 50 & 17,0 & 16,0 & 17,0 & 17,0 & 17,0 & 16,0 \\
\hline 75 & 18,0 & 18,0 & 19,0 & 19,0 & 19,0 & 18,0 \\
\hline 90 & 20,0 & 19,0 & 20,0 & 20,0 & 20,0 & 19,0 \\
\hline 95 & 20,0 & 20,0 & 20,0 & 20,0 & 20,0 & 20,0 \\
\hline \multicolumn{7}{|c|}{ Zadovoljstvo sobom (8) } \\
\hline Precentili & Uk. & M & $\check{z}$ & 3. $R$. & 5. R. & 7.R. \\
\hline 5 & 9,0 & 9,0 & 8,0 & 9,0 & 9,0 & 8,0 \\
\hline 10 & 10,0 & 10,0 & 10,0 & 11,0 & 10,0 & 9,0 \\
\hline 25 & 12,0 & 12,0 & 12,0 & 12,0 & 12,0 & 11,0 \\
\hline 50 & 13,0 & 13,0 & 14,0 & 14,0 & 14,0 & 13,0 \\
\hline 75 & 15,0 & 15,0 & 15,0 & 15,0 & 15,0 & 14,0 \\
\hline 90 & 15,0 & 15,0 & 15,0 & 15,0 & 15,0 & 15,0 \\
\hline 95 & 15,0 & 15,0 & 15,0 & 15,0 & 15,0 & 15,0 \\
\hline \multicolumn{7}{|c|}{ Permisivnost u odgoju (9) } \\
\hline Precentili & Uk. & M & ž & 3. $R$. & 5. $R$. & 7.R. \\
\hline 5 & 6,4 & 6,0 & 7,0 & 7,0 & 7,0 & 6,0 \\
\hline
\end{tabular}


Dejana Bouillet: Procjena potreba učenika osnovne škole u svrhu planiranja socijalnopedagoških intervencija...

\begin{tabular}{|l|c|c|c|c|c|c|}
\hline $\mathbf{1 0}$ & 8,0 & 8,0 & 8,0 & 8,0 & 8,0 & 7,0 \\
\hline $\mathbf{2 5}$ & 10,0 & 9,0 & 10,0 & 10,0 & 10,0 & 9,0 \\
\hline $\mathbf{5 0}$ & 12,0 & 11,0 & 12,0 & 12,0 & 12,0 & 11,0 \\
\hline $\mathbf{7 5}$ & 13,0 & 13,0 & 14,0 & 14,0 & 14,0 & 13,0 \\
\hline $\mathbf{9 0}$ & 15,0 & 15,0 & 15,0 & 15,0 & 15,0 & 14,0 \\
\hline $\mathbf{9 5}$ & 15,0 & 15,0 & 15,0 & 15,0 & 15,0 & 15,0 \\
\hline
\end{tabular}

Iz podataka prikazanih u tablici 7 proizlazi da se učenici međusobno različito razlikuju u postignutim rezultatima na pojedinim faktorima, s obzirom na njihovu dob i spol. Razlike su najmanje na faktoru procjene odnosa s vršnjacima, a najveće na faktorima procjena odnosa prema obrazovanju i prema obvezama. Navedeno podrazumijeva da prilikom razvrstavanja učenika u kategoriju s teškoćama u ponašanju, poremećajima u ponašanju i ostale učenike, u vidu treba imati njihovu dob i spol. Za potrebe ovog istraživanja, grupe su formirane na temelju razreda kojeg učenik pohađa, budući da je F-omjerom utvrđeno da razred kojeg učenici pohađaju kvalitetno diskriminira ispitanike prema dobi (F-omjer $=20940,125, p=, 000$ ). Rezultati dobiveni analizom tako formiranih grupa, prikazani su u tablici 8.

Tablica 8 Distribucija ispitanika prema manifestiranju problema u ponašanju (\%), vrijednosti i značajnost t-testa i Pearsonove korelacije grupa s neovisno utvrđenim kriterijem manifestiranja problema u ponašanju učenika

\begin{tabular}{|c|c|c|c|c|c|c|c|}
\hline Faktor & $\begin{array}{l}\text { Učenici s } \\
\text { PUP }\end{array}$ & $\begin{array}{l}\text { Učenici s } \\
\text { TUP }\end{array}$ & $\begin{array}{l}\text { Ukupno učenici } \\
\text { s PUP }\end{array}$ & T-test & $\mathbf{p}$ & Pearsonov koef. & $\mathbf{P}$ \\
\hline Odnos s vršnjacima (1) & 5,6 & 5,4 & 11,0 & 49,416 &, 000 &, 069 &, 000 \\
\hline Odnos prema obrazovanju (2) & 7,4 & 4,9 & 12,3 & 215,277 &, 000 &, 147 &, 000 \\
\hline Odnos prema obvezama (3) & 6,3 & 7,1 & 13,4 & 14,274 &, 000 &, 036 &, 040 \\
\hline Odnos s roditeljima (4) & 7,0 & 4,4 & 11,4 & 107,035 &, 000 &, 100 &, 000 \\
\hline Razina roditeljske podrške (5) & 4,9 & 7,5 & 12,5 & 35,491 &, 000 &, 055 &, 002 \\
\hline $\begin{array}{l}\text { Otvorenost u komunikaciji i } \\
\text { interesima (6) }\end{array}$ & 7,0 & 7,9 & 15,0 & 59,103 &, 000 &, 071 &, 000 \\
\hline Odnos s razrednikom (7) & 7,9 & 5,6 & 13,5 & 53,858 &, 000 & ,068 &, 000 \\
\hline Zadovoljstvo sobom (8) & 6,7 & 8,7 & 15,4 & 127,346 &, 000 & 115 &, 000 \\
\hline Permisivnost u odgoju (9) & 7,1 & 4,3 & 11,4 & 37,709 &, 000 &, 058 & 001 \\
\hline
\end{tabular}

PUP = poremećaji u ponašanju; TUP = teškoće u ponašanju

Uvidom u podatke prikazane u tablici 8 moguće je zaključiti da teškoće u ponašanju i poremećaje u ponašanju prema samoprocjeni učenika manifestira $12,88 \%$ učenika u uzorku istraživanja, što se može smatrati i udjelom učenika s problemima u ponašanju u populaciji učenika osnovnoškolske dobi u Hrvatskoj (s obzirom na strukturu uzorka koja obuhvaća učenike mlađe i starije školske dobi). Model prikazane distribucije učenika potvrđen je dvostupanjskom klaster analizom koja je rezultirala dobrom kohezivnošću i separativnošću grupa učenika prema kriteriju manifestiranja problema u ponašanju (slika 1). 
Model Summary

\begin{tabular}{|c|c|}
\hline Algorithm & TwoStep \\
\hline Inputs & 9 \\
\hline Clusters & 2 \\
\hline
\end{tabular}

Cluster Quality

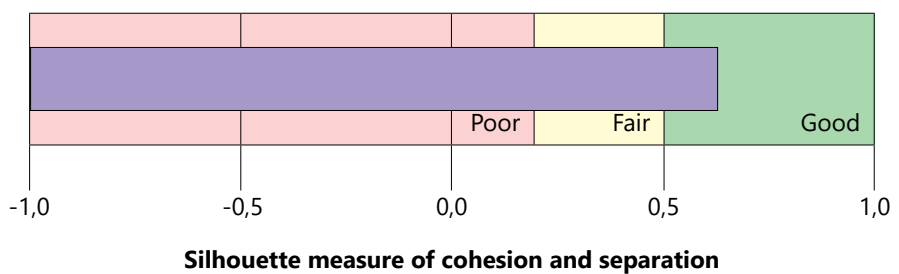

Slika 1 Kohezivnost i separativnost utvrđenih grupa prema kriteriju manifestiranja problema u ponašanju učenika

Prema tome, u planiranju uključivanja učenika u socijalnopedagoške intervencije i planiranje njihovog sadržaja moguće je rukovoditi se kriterijima koji su prikazani u tablici 9, povezujući sadržaj intervencija s iskazanim potrebama učenika i, kada je moguće i potrebno, uključujući u intervenciju stručnjake drugih profila (npr. psihologe, edukacijske rehabilitatore, logopede, socijalne radnike, liječnike). Pri tome se istom intervencijom može (a u pravilu se to i događa) djelovati na više područja intervencije. Primjerice, treningom socijalnih vještina moguće je djelovati na područje odnosa prema vršnjacima, otvorenosti u komunikaciji i interesima, odnosu s razrednikom i obiteljske odnose, dok je vršnjačkom pomoći i mentorskim programima podrške moguće djelovati na područje odnosa prema obrazovanju, odnosa prema obvezama, zadovoljstvu sobom i na odnos s vršnjacima.

Tablica 9 Kriteriji za uvrštavanje učenika u grupu s problemima u ponašanju i planiranje intervencije izraženi u broju bodova postignutima na Upitniku za procjenu potreba učenika za socijalnopedagoškim intervencijama - verzija za učenike

\begin{tabular}{|l|c|c|c|c|c|c|}
\cline { 2 - 6 } \multicolumn{1}{c|}{} & \multicolumn{2}{c|}{ 3. RAZRED } & \multicolumn{2}{c|}{ 5. RAZRED } & \multicolumn{2}{c|}{ 7. RAZRED } \\
\hline Faktor & Učenici s PUP & Učenici s TUP & Učenici s PUP & Učenici s TUP & Učenici s PUP & Učenici s TUP \\
\hline Odnos s vršnjacima (1) & $0-21$ & $22-24$ & $0-21$ & $22-24$ & $0-21$ & $22-23$ \\
\hline Odnos prema obrazovanju (2) & $0-16$ & 17 & $0-14$ & $15-16$ & $0-12$ & 13 \\
\hline Odnos prema obvezama (3) & $0-10$ & $11-12$ & $0-11$ & 12 & $0-9$ & $10-11$ \\
\hline Odnos s roditeljima (4) & $0-18$ & $19-20$ & $0-18$ & $19-20$ & $17-18$ \\
\hline Razina roditeljske podrške (5) & $0-8$ & $9-11$ & $0-9$ & $10-11$ & $0-8$ & $9-11$ \\
\hline $\begin{array}{l}\text { Otvorenost u komunikaciji i } \\
\text { interesima (6) }\end{array}$ & $0-16$ & $17-18$ & $0-16$ & $17-19$ & $0-17$ & $18-19$ \\
\hline Odnos s razrednikom (7) & $0-12$ & 13 & $0-12$ & 13 & $0-9$ & $10-11$ \\
\hline Zadovoljstvo sobom (8) & $0-9$ & $10-11$ & $0-9$ & 10 & $0-8$ & 9 \\
\hline Permisivnost u odgoju (9) & $0-7$ & 8 & $0-7$ & 8 & $0-6$ & 7 \\
\hline UKUPNI REZULTAT (od 210) & 117 & 134 & 117 & 133 & 106 & 112 \\
\hline
\end{tabular}

PUP = poremećaji u ponašanju; TUP = teškoće $u$ ponašanju 
Dejana Bouillet: Procjena potreba učenika osnovne škole u svrhu planiranja socijalnopedagoških intervencija...

Budući da rezultati na Upitniku ovise i o rodnoj pripadnosti učenika (tablica 7), norme prikazane u tablici 9 potrebno je tumačiti i s obzirom na to radi li se o učenici ili učeniku. U tablici 10 prikazani su smjerovi u kojima se spol učenika može reflektirati na svrstavanje učenika u pojedinu grupu.

Tablica 10 Utjecaj spola na uvrštavanje učenika u grupu s problemima u ponašanju i planiranje intervencije izraženi u broju bodova postignutima na Upitniku za procjenu potreba učenika za socijalnopedagoškim intervencijama - verzija za učenike

\begin{tabular}{|l|c|c|c|c|c|c|}
\cline { 2 - 7 } \multicolumn{1}{c|}{} & \multicolumn{2}{c|}{ 3. RAZRED } & \multicolumn{2}{c|}{ 5. RAZRED } & \multicolumn{2}{c|}{ 7. RAZRED } \\
\hline Faktor & Učenici & Učenice & Učenici & Učenice & Učenici & Učenice \\
\hline Odnos s vršnjacima (1) & - & - & - & - & - & - \\
\hline Odnos prema obrazovanju (2) & -3 boda & -2 boda & -1 bod & - & +1 bod & +2 boda \\
\hline Odnos prema obvezama (3) & -2 boda & +1 bod & -1 bod & - & - & +2 boda \\
\hline Odnos s roditeljima (4) & -1 bod & - & - & - & +1 bod & +2 boda \\
\hline Razina roditeljske podrške (5) & - & +2 boda & -1 bod & +2 boda & - & +2 boda \\
\hline Otvorenost u odnosima (6) & - & - & - & - & -1 bod & -1 bod \\
\hline Odnos s razrednikom (7) & -2 boda & - & -2 boda & - & +1 bod & +3 boda \\
\hline Zadovoljstvo sobom (8) & - & -1 bod & - & -1 bod & - & - \\
\hline Odgojni stilovi (9) & -1 bod & - & -1 bod & - & - & +1 bod \\
\hline UKUPNA RAZLIKA & 9 & 0 & 6 & 1 & 2 & 11 \\
\hline
\end{tabular}

Sudeći prema rezultatima prikazanima u tablici 9, prilikom razmatranja potreba učenika za uključivanjem u socijalnopedagoške intervencije, razložno je uzeti u obzir spol učenika te rezultat učenika na Upitniku tumačiti s obzirom na njegov spol i dob. Granica problema u ponašanju za učenike trećih razreda proširuje se za 9 bodova za učenike, dok za učenice ostaje nepromijenjena. Kada se radi o učenicima petih razreda, granica za učenike se proširuje za 6, a za učenice za 1 bod. Granice učenika 7 razreda šire se za 2, a za učenice za čak 11 bodova.

Treba naglasiti da se radi o radnim normama koje će se dodatno provjeriti u sljedećoj fazi projekta, na uzorku učenika s problemima u ponašanju u školama u kojima će se provoditi i evaluirati socijalnopedagoške intervencije temeljene na Upitniku za procjenu potreba učenika za socijalnopedagoškim intervencijama - verziji za učenike.

\section{Rasprava i zaključak}

U ovom je radu prikazan dio istraživanja provedenog u sklopu projekta Razvoj modela socijalnopedagoških intervencija u osnovnoj školi Agencije za odgoj i obrazovanje koji se provodi od rujna 2015. godine, u dijelu koji se odnosi na razvoj mjernog instrumenta za pravovremenu identifikaciju problema u ponašanju učenika osnovnih škola, temeljem samoprocjene učenika, kako bi se osigurali preduvjeti za evaluaciju socijalnopedagoških intervencija u školskom okruženju, a to su: (a) standardizirani postupak identifikacije učenika s problemima u ponašanju te (b) utvrđivanje potreba učenika za socijalnopedagoškom intervencijom. Prema rezultatima istraživanja, stvoreni su početni uvjeti za standardizaciju postupka identifikacije učenika s problemima u ponašanju u osnovnoj školi, u vidu Upitnika za procjenu potreba učenika za socijalnopedagoškim intervencijama - verzije za učenike jer su statističke analize pokazale da on primjereno razlikuje učenike s problemima u ponašanju od ostalih učenika. Također je potvrđeno da grupiranje učenika 
u skupine s poremećajima i teškoćama u ponašanju ovisi o njihovom spolu i dobi. Međutim, Upitnik je standardiziran na uzorku učenika osnovne škole u općoj populaciji, pa će njegova daljnja primjena u školama s učenicima s problemima u ponašanju vjerojatno pridonijeti novim saznanjima i mogućim izmijenjenim verzijama ove, početne, varijante Upitnika. Iz tog razloga, norme utvrđene ovim istraživanjem potrebno je dalje razvijati, osobito imajući u vidu potrebu primjene Upitnika u svim dobnim skupinama.

Iznimno je važno imati u vidu da se radi o pomoćnom sredstvu planiranja socijalnopedagoških intervencija koje ni na koji način ne može zamijeniti uobičajene postupke socijalnopedagoške procjene potreba i problema učenika. Ipak, njegova primjena može znatno unaprijediti rad socijalnih pedagoga u školama, jer rezultat na Upitniku daje dovoljno informacija o intervencijskim potrebama učenika, u odnosu na sva područja socijalnopedagoškog djelovanja. To su vršnjački odnosi, obrazovanje, radne navike, obiteljski odnosi (uključujući i procjenu odgojnih stilova roditelja i učitelja), odnos prema autoritetima, slika o sebi i socijalne vještine. Upitnik primijenjen u ovom istraživanju mjeri odnos učenika s razrednikom, kako bi se točno znalo koga učenik procjenjuje, ali je te čestice $u$ individualnom radu s učenikom moguće preoblikovati i mjeriti odnos učenika s bilo kojim učiteljem.

Što se udjela učenika s problemima u ponašanju tiče, početnih $14,4 \%$ učenika koje su socijalni pedagozi u istraživanju identificirali kao učenike s problemima u ponašanju je putem statističkih analiza svedeno na 12,9\%. Ova razlika od 1,5\% je dijelom posljedica okolnosti da se dio učenika u prvobitnom skupu odnosi na učenike rizičnog ponašanja, načina formiranja skupina ispitanika prema kriteriju problema u ponašanju (učenici s poremećajima u ponašanju, učenici s teškoćama u ponašanju i ostali učenici) i činjenici da se u ovom slučaju radi o samoprocjenama učenika. Iz literature je, naime, poznato da su učenici restriktivniji u procjenama problema u ponašanju u odnosu na ostale sudionike procjena njihovih problema i potreba (Bouillet, 2015b, Pevin Ivanec, 2015).

Grupiranje učenika prema problemima u ponašanju je u ovom istraživanju izvršeno prema razredu kojeg učenici pohađaju, dok će se normiranje prema spolu izvršiti u budućim fazama projekta. Ipak, hipoteza kojom je pretpostavljeno da će udio učenika s problemima u ponašanju u populaciji učenika osnovnoškolske dobi biti u skladu s ranije provedenim istraživanjima, odnosno do $15 \%$ je potvrđena, što dodatno upućuje na valjanost, objektivnost i pouzdanost razvijenog mjernog instrumenta.

\section{Literatura}

Abu-Rayya, H.M., Yang, B. (2012): Emotional and Behavioral Problems and Their Underlying Risk Factors Among Children in New South Wales. International Journal of Mental Health, 41(3). 3-23.

Barnett, W.S. (2011): Effectiveness of Early Educational Intervention. Science, 333(19). 975-978.

Bouillet, D. (2011): Socijalnopedagoška praksa i potrebe korisnika, U: Poldrugač, Z., Bouillet, D., Ricijaš, N. (ur.): Socijalna pedagogija: znanost, profesija i praksa u Hrvatskoj, Zagreb: Edukacijsko-rehabilitacijski fakultet Sveučilišta u Zagrebu, 131-151. 
Bouillet, D., (2015a): Konceptualni okvir razvoja modela rane odgojno-obrazovne intervencije. U: Bouillet, D. (ur.): Razvoj modela rane odgojno-obrazovne intervencije u osnovnoj školi: od ideje do evaluacije, Zagreb: Forum za slobodu odgoja. 25-47.

Bouillet, D. (2015b): Procjena i samoprocjena problema u ponašanju učenika razredne nastave: prilike i izazovi. Kriminologija i socijalna integracija, 22(1). 105-128, http://hrcak.srce. hr/132684.

Boydell Brauner, Ch., Bowers Stephans, Ch. (2006): Estimating the Prevalence of Early Childhood Serious Emotional/Behavioral Disorders: Challenges and Recommendations, Public Health Report, 121(3). 303-310.

Conley, L., Marchant, M., Caldarella, P. (2014): A comparison of teacher perceptions and research-based categories of student behavior difficulties. Education, 134(4). 439450.

Conroy, M.A:, Brown, W.H. (2004): Early Identification, Prevention, and Early Intervetion with Young Children At Risk for Emotinal or Behavioral Disorders: Issues, Trends, ad a Call for Action. Behavioural Disorders, 29(3). 224-236.

Eklund, K., Renshaw, T.L., Dowdy, E., Jimerson, Sh.R., Hart, Sh.R., Jones, C.N., Earhart, J. (2009): Early Identification og Behavioral and Emotional Problem sin Youth: Universal Screening versus Teacher-Referral Identification. The California School Psychologist, 14. 89-95.

Gable, R.A. (2004): Hard Times and an Uncertain Future: Issues that Confront the Field of Emotional/Behavioral Disorders. Education and Treatment of Children, 27(4). 341352.

George, D., Mallery, M. (2010): SPSS for Windows Step by Step: A Simple Guide and Reference. Boston: Pearson.

Koller-Trbović, N., Mirosavljević, A., Jeđud Borić, I. (2013): Procjena intervencijskih potreba djece i mladih s problemima u ponašanju. U: Žižak, A., Koller-Trbović, N., ur.: Procjena rizika i snaga u funkciji planiranja tretmana: Rezultati znanstvenog projekta: Usklađivanje intervencija s potrebama djece i mladih u riziku: izrada modela. Zagreb: Edukacijsko-rehabilitacijski fakultet Sveučilišta u Zagrebu, 23-66.

Koller-Trbović, N., Nikolić, B., Dugandžić, V.(2009): Procjena čimbenika rizika kod djece i mladih u riziku ili s poremećajima u ponašanju. Hrvatska revija za rehabilitacijska istraživanja, 45(2). 37-54.

Koller-Trbović, N., Žižak, A. (2012): Problemi u ponašanju djece i mladih i odgovori društva: višestruke perspektive. Kriminologija i socijalna integracija, 20(1). 49-62.

Koller-Trbović, N., Žižak, A., Jeđud Borić, I. (2011): Standardi za terminologiju, definiciju, kriterije i način praćenja pojave poremećaja u ponašanju djece i mladih. Zagreb: Ministarstvo obitelji, branitelja i međugeneracijske solidarnosti.

Konvencija o pravima djeteta (1990.). Službeni list - Međunarodni ugovori 15/90. Narodne novine - Međunarodni ugovori 12/93. 20/97.

Kyriacou, Ch. (2009): The five dimensions of social pedagogy within schools. Pastoral Care in Education, 27(2). 101-108.

Kyriacou, Ch., Tollisen Ellingsen, I., Stephens, P., Sundaram, V. (2009): Social pedagogy and the teacher: England and Norway compared. Culture \& Society, 17(1). 75-87. 
Okvir za poticanje i prilagodbu iskustva učenja te vrednovanje postignuća djece i učenika s teškoćama (2016), prijedlog Nacionalnog dokumenta. http://www.kurikulum.hr/ wp-content/uploads/2016/02/Okvir-djeca-i-ucenici-s-teskocama.pdf (posjećeno 29.8.2016..)

Pastor, P.N., Reuber, C.A, Duran, C.R. (2012): Identifying Emotional and Behavioral Problem sin Children Aged 4-17 Years: United States, 2011-2007. National Health Statistics Reports. Number 48." National Center for Health Statistics.

Pavin Ivanec, T. (2015): Potrebe učenika za ranom odgojno-obrazovnom intervencijom: fenomenologija i rasprostranjenost problema u ponašanju. U: Bouillet, D. (ur.): Razvoj modela rane odgojno-obrazovne intervencije u osnovnoj školi: od ideje do evaluacije, Zagreb, Forum za slobodu odgoja. 33-47.

Smith, M., Whyte, B. (2008): Social education and social pedagogy: reclaming a Schottish tradition in social work. European Journal of Social Work, 11(1). 15-28.

Statističko priopćenje: Osnovno škole - kraj šk. god. 2014./2015. i početak šk. god. 2015./2016. Državni zavod za statistiku, http://www.dzs.hr/ (posjećeno 25.8.2016.)

Stevens, I. (2010): Social Pedagogy and its links to Holding the Space. Glasgow: Scottish Institute for Residential Child Care - SIRCC.

Storø, J. /2013): Practical Social Pedagogy: Theories, values and tools for working with children and young people. Bristol, The Policy Press.

Strategija obrazovanja, znanosti i tehnologije. Narodne novine 124/14.

Tabachnick, B.G., Fidell, L.S. (2001): Using Multivariate Statistics. Boston: Allyn and Bacon.

Žižak, A. (2010): Teorijske osnove intervencija - socijalnopedagoška perspektiva. Zagreb: Edukacijsko-rehabilitacijski fakultet Sveučilišta u Zagrebu.

Žižak, A., Koller-Trbović, N., ur (2013): Procjena rizika i snaga u funkciji planiranja tretmana: Rezultati znanstvenog projekta: Usklađivanje intervencija s potrebama djece i mladih u riziku: izrada modela. Zagreb: Edukacijsko-rehabilitacijski fakultet Sveučilišta u Zagrebu. 